\title{
MEMBANGUN MODEL DINAMIS PENANGKARAN POPULASI MALEO (Macrochepalon Maleo) YANG MEMPERTAHANKAN EKSISTENSINYA DARI PREDATOR
}

\author{
T. Gusmawan', R. Ratianingsih², N. Nacong ${ }^{3}$ \\ 1,2,3Program Studi Matematika Jurusan Matematika FMIPA Universitas Tadulako \\ Jalan Soekarno-Hatta Km. 09 Tondo, Palu 94118, Indonesia \\ 1trygusmawan@gmail.com, 3ratianingsih@yahoo.com, 2nasrianacong@gmail.com
}

\begin{abstract}
Maleo (Macrocephalon maleo) is one of the endangered endemic species of Sulawesi due to diminishing spawning habitat, community exploitation and predators. The dynamic model of maleo population captivity to conserve its existence from predators is a mathematical model that describes the dynamics of maleo population growth cycle (M) with the threat of predators $(P)$. In this study, the population of eggs maleo divided into two groups that are eggs in the free zone ( $\mathrm{Tb}$ ) and eggs in breeding (Tp). The eggs are in the captive breeding will be transfered to the exposure group $(E)$. The model represents the interaction between the predators and populations reflecting maleo in each growth phase. The model has two critical points, namely the critical point $T_{1}=\left(0,0,0,0, \frac{\varphi}{\mu_{2}}\right)$ describing maleo extinction condition and critical point $T_{2}=\left(M^{*}, T p^{*}, E^{*}, T b^{*}, P^{*}\right)$ which describes the endemic conditions of maleo growth dynamics. The stability analysis shows that the system is unstable at both critical points. It is because the values of the first column in the Routh Hurwitz table changes in sign. Simulations of the endemic conditions showed that the maleo and egg populations in the free zone are decreasing with respect to time even though the exposed maleo still exist. The unstable endemic indicates that the existence of maleo breeding program in conservation areas still need another efforts support.
\end{abstract}

Keywords $\quad$ : Breeding, Linearization, Maleo (Macrocephalon maleo), Routh Hurwitz, Stability Analysis.

\section{ABSTRAK}

Maleo (Macrocephalon maleo) merupakan salah satu satwa endemik Sulawesi yang terancam punah akibat berkurangnya habitat peneluran, eksploitasi masyarakat dan predator. Model dinamis penangkaran populasi maleo yang mempertahankan eksistensinya dari predator merupakan suatu model matematika yang menggambarkan dinamika siklus pertumbuhan populasi maleo $(M)$ dengan ancaman predator $(P)$. Pada penelitian ini, telur maleo dibagi menjadi 2 kelompok yaitu telur di alam bebas $(T b)$ dan telur di penangkaran (Tp). Telur di penangkaran yang menetas dimasukkan dalam kelompok ekspous (E). Interaksi antara predator dan populasipopulasi yang mencerminkan perpindahan fase pertumbuhan maleo dinyatakan dalam suatu model matematika. Model tersebut menghasilkan dua titik kritis, yaitu titik kritis $T_{1}=\left(0,0,0,0, \frac{\varphi}{\mu_{2}}\right)$ yang menggambarkan kondisi punah maleo dan titik kritis $T_{2}=\left(M^{*}, T p^{*}, E^{*}, T b^{*}, P^{*}\right)$ yang menggambarkan kondisi endemik dinamika pertumbuhan maleo. Hasil analisa kestabilan menunjukkan sistem dikedua titik kritisnya tidak stabil. Hal ini disebabkan nilai-nilai dari kolom pertama pada tabel Routh Hurwitz mengalami perubahan tanda. Simulasi pada kondisi endemik 
memperlihatkan bahwa seiring berjalannya waktu, populasi maleo dan telurnya yang berada di alam bebas mengalami penurunan jumlah populasi sedangkan populasi ekspous tetap eksis. Kondisi endemik yang tidak stabil mengindikasikan upaya untuk menjaga eksistensi maleo melalui penangkaran di wilayah konservasi masih memerlukan dukungan upaya lain.

Kata Kunci : Penangkaran, Linierisasi, Maleo (Macrocephalon maleo), Routh Hurwitz, Analisis Kestabilan.

\section{PENDAHULUAN}

Dalam zona Wallacea, Sulawesi merupakan yang terkaya, paling banyak jenis endemiknya dan dunia burungnya yang sangat berbeda dengan tempat lain (Coates dkk dalam Laan, 2007). Maleo (Macrocephalon maleo) merupakan salah satu jenis burung endemik Sulawesi yang sangat unik dan banyak menarik perhatian. Spesies ini telah dimasukkan ke dalam kategori satwa yang terancam punah akibat semakin menurunnya populasi dan banyak hilangnya habitat peneluran (Collar dkk,1994).

Penyebaran maleo (Macrocephalon maleo) di Sulawesi relatif luas, terutama di Sulawesi Utara dan Sulawesi Tengah. Salah satu kawasan konservasi yang dikenal sebagai habitat maleo (Macrocephalon maleo) adalah kawasan Taman Nasional Lore Lindu (TNLL) di Kabupaten Sigi Propinsi Sulawesi Tengah. Populasi maleo (Macrocephalon maleo) di TNLL Sulteng terancam akibat kerusakan habitat, eksploitasi oleh masyarakat dan predator sehingga upaya pelestarian perlu dilakukan. koordinator lapangan pelestarian burung maleo Balai Taman Nasional Lore Lindu, satwa liar yang menjadi pemangsa burung maleo dan telurnya antara lain biawak, ular dan burung elang. Namun dari ke tiga predator tersebut, gangguan terbesar dalam melestarikan burung Maleo datang dari predator alamnya, yakni biawak (Sasia, 2016).

Salah satu model yang bisa dimanfaatkan untuk mendukung pelestarian maleo adalah model diamis penangkaran populasi maleo. Model dinamis penangkaran populasi maleo yang mempertahankan eksistensinya dari predator merupakan suatu model matematika yang menggambarkan dinamika siklus pertumbuhan populasi maleo dengan ancaman predator. Pada penelitian ini, telur maleo dibagi menjadi dua kelompok yaitu telur di alam bebas dan telur di penangkaran. Telur di penangkaran yang menetas dimasukkan dalam kelompok ekspous. Model yang dibangun akan dianalisa kestabilan sistem disekitar titik kritisnya dengan menggunakan metode linearisasi. Sebagai deskripsi dari model, dilakukan simulasi untuk mendapatkan gambaran kecocokan model yang dibangun dengan keadaan real di lapangan.

\section{METODE PENELITIAN}

Penelitian ini merupakan tinjauan matematis terhadap interaksi antara predator dan populasipopulasi yang mencerminkan perpindahan fase pertumbuhan maleo dengan model matematika melalui analisa kestabilan di titik kritis sistem. Metode yang digunakan adalah metode linearisasi. Linearisasi adalah proses hampiran sistem persamaan diferensial tak linier dengan sistem persamaan 
diferensial linier yang ekivalen. Linearisasi digunakan untuk menyelesaikan sistem autonomous yang berbentuk

$\left.\begin{array}{l}\frac{d x}{d t}=f(x, y) \\ \frac{d y}{d t}=g(x, y)\end{array}\right\}$

dimana $f(x, y)$ dan $g(x, y)$ adalah persamaan tak linear. Jika $\left(x_{0}, y_{0}\right)$ merupakan titik kritis dari sistem persamaan ( 1 ), maka :

$f\left(x_{0}, y_{0}\right)=0$ dan $g\left(x_{0}, y_{0}\right)=0$

Kestabilan dari titik kritis dapat diamati melalui nilai eigen yang memenuhi $f(\lambda)=\operatorname{det}(\lambda I-J)=0$, dimana $J=\left[\begin{array}{ll}f_{x}\left(x_{0}, y_{0}\right) & f_{y}\left(x_{0}, y_{0}\right) \\ g_{x}\left(x_{0}, y_{0}\right) & g_{y}\left(x_{0}, y_{0}\right)\end{array}\right]$ adalah matriks Jacobi yang dievaluasi dititik kritis $\left(x_{0}, y_{0}\right)$. Ukuran matriks tergantung pada banyaknya persamaan yang menyusun sistem persamaan differensial yang linear (Campbell \& Haberman, 2008).

\subsection{Descartes' Rule of Sign}

Descartes' Rule of Sign merupakan cara untuk mengetahui jumlah akar-akar positif dan negatif. Misalkan $p(\lambda)$ adalah polinomial atas variable $\lambda$ dengan koefisien real dan kostanta tidak nol, maka banyaknya akar-akar persamaan yang mungkin dapat dicari dengan descartes' rule of sign, yaitu

a. Banyaknya akar penyelesaian positif dari $p(\lambda)=0$ sama dengan atau kurang dari jumlah variasi (perubahan) tanda pada koefisien $p(\lambda)$.

b. Banyaknya akar penyelesaian negatif dari $p(\lambda)=0$ sama dengan atau kurang dari jumlah variasi (perubahan) tanda pada koefisien $p(-\lambda)$.

Perubahan tanda pada polinomial ini dapat dilihat dari tanda positif ke tanda negatif atau sebaliknya. ( Drucker, D.S. 1979).

\subsection{Routh-Hurwitz}

Kriteria kestabilan Routh-Hurwitz adalah suatu metode yang mengkaji kestabilan sistem dengan hanya memperhatikan koefisien dari persamaan karateristik tanpa menghitung akarakar karateristik secara langsung. Diberikan suatu persamaan karateristik dengan orde ke-n sebagai berikut :

$f(\lambda)=a_{0} \lambda^{n}+a_{1} \lambda^{n-1}+a_{2} \lambda^{n-2}+\cdots+a_{n-1} \lambda+a_{n}=0$ 
Tabel 1 : Kriteria Routh-Hurwitz

\begin{tabular}{|ccccc|}
\hline$\lambda^{n}$ & $a_{n}$ & $a_{n-2}$ & $a_{n-4}$ & $\ldots .$. \\
$\lambda^{n-1}$ & $a_{n-1}$ & $a_{n-3}$ & $a_{n-5}$ & $\ldots .$. \\
$\lambda^{n-2}$ & $b_{1}$ & $b_{2}$ & $b_{3}$ & $\ldots .$. \\
$\lambda^{n-3}$ & $c_{1}$ & $c_{2}$ & $c_{3}$ & $\ldots .$. \\
$\lambda^{n-3}$ & $d_{1}$ & $d_{2}$ & $d_{3}$ & $\ldots .$. \\
$\vdots$ & $\vdots$ & $\vdots$ & $\vdots$ & $\ldots .$. \\
$\lambda^{2}$ & $e_{1}$ & $e_{2}$ & & $\ldots .$. \\
$\lambda$ & $f_{1}$ & & & $\ldots .$. \\
$\lambda^{0}$ & $g_{1}$ & & & \\
\hline
\end{tabular}

Nilai $b_{1}, b_{2}, b_{3}, c_{1}, c_{2}$ dan $c_{3}$ pada tabel 1 diperoleh dari perhitungan berikut ini :

$$
\begin{array}{cc}
b_{1}=\frac{a_{n-1} a_{n-2}-a_{0} a_{n-3}}{a_{n-1}} & c_{1}=\frac{b_{1} a_{n-3}-a_{n-1} b_{2}}{b_{1}} \\
b_{2}=\frac{a_{n-1} a_{n-4}-a_{n} a_{n-5}}{a_{n-1}} & c_{2}=\frac{b_{1} a_{n-5}-a_{n-1} b_{3}}{b_{1}} \\
\vdots & \vdots \\
b_{n}=\frac{a_{1} a_{2 n}-a_{0} a_{2 n+1}}{a_{1}} & c_{n}=\frac{b_{1} a_{2 n+1}-a_{1} b_{n+1}}{b_{1}}
\end{array}
$$

Dengan menggunakan akar karakteristik (nilai eigen $\lambda$ ), sistem dikatakan stabil jika dan hanya jika elemen-elemen pada kolom pertama $\left(a_{0}, b_{1}, c_{1}, \ldots\right)$ memiliki tanda yang sama atau tidak ada perubahan tanda pada kolom pertama (Subiono, 2013).

\section{HASIL DAN PEMBAHASAN}

\subsection{Kontruksi Model}

Penelitian ini mengasumsikan pemangsaan predator hanya terjadi di alam bebas wilayah konservasi. Model matematika yang menggambarkan dinamika siklus pertumbuhan populasi maleo $(M)$ dengan ancaman predator $(P)$ yang hidup dalam ekosistem Taman Nasional Lore Lindu (TNLL). Pertumbuhan maleo yang hidup bebas di TNLL mengikuti hukum Logistik. Telur yang dihasilkam maleo, yang berhasil dikumpulkam oleh petugas dari alam bebas, ditempatkan dalam penangkaran dengan proposi sebesar $(\alpha)$. Dengan persentase maleo bertelur sebesar $(\theta)$, maka banyaknya terlur dalam penangkaran adalah sebesar $(\alpha \theta M)$. Maleo dan telur yang menetas di penangkaran dengan persentase sebesar $(\beta)$ tidak langsung dilepas bebas di TNLL, namun diadaptasikan terlebih dahulu dan dimasukkan dalam kelompok ekspous (E). Setelah siap, maleo dilepas bebas di TNLL dengan persentase sebesar $(\gamma)$.

Telur yang tidak berhasil dikumpulkan petugas, sebanyak $(\theta(1-\alpha) M)$, akan terancam dimakan oleh predator dengan tingkat predasi sebesar $(\rho)$. Telur yang berhasil menetas diluar penangkaran dengan prensentase sebesar $(1-\rho)$ akan menjadi kelompok populasi maleo. 
Predator tidak hanya memakan telur maleo saja namun juga memburu maleo dengan tingkat predasi sebesar $\delta$. Alur perpindahan siklus maleo dan interaksinya dengan predator digambarkan dalam diagram kompartemen pada Gambar 1.

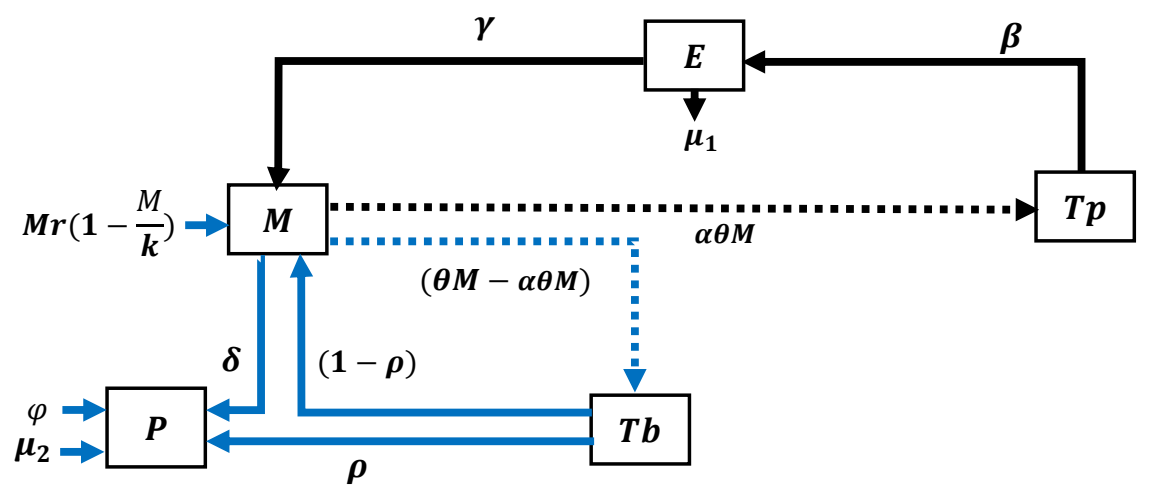

Gambar 1: Diagram Kompartemen Dinamika Model Penangkaran Populasi Maleo

Tabel 2 : Parameter dan Deskripsi

\begin{tabular}{|c|l|}
\hline Parameter & \\
\hline$r$ & Laju pertumbuhan maleo \\
\hline$\varphi$ & Laju pertumbuhan predator \\
\hline$\beta$ & Persentase telur maleo yang menetas menjadi populasi ekspous \\
\hline$\mu_{1}$ & Tingkat kematian alami maleo pada masa ekspous \\
\hline$\mu_{2}$ & Tingkat kematian alami predator \\
\hline A & $\begin{array}{l}\text { Persentase telur yang dipindahkan dari alam bebas wilayah konservasi } \\
\text { kepenangkaran }\end{array}$ \\
\hline$\gamma$ & $\begin{array}{l}\text { Koefisien perpindahan populasi } e k s p o u s \text { dari penangkaran ke alam bebas } \\
\text { wilayah konservasi }\end{array}$ \\
\hline$\rho$ & Tingkat pemangsaan predator terhadap telur maleo \\
\hline$(1-\alpha)$ & Persentase telur yang tetap berada di alam bebas wilayah konservasi \\
\hline$(1-\rho)$ & Persentase telur yang berhasil menestas di alam bebas wilayah konservasi \\
\hline$\delta$ & Tingkat pemangsaan predator terhadap maleo \\
\hline$\theta$ & Persentase maleo yang bertelur \\
\hline & Daya tampung (carryng capacity) \\
\hline
\end{tabular}


Dari diagram kompartemen pada Gambar 1 dibangun model dinamis penangkaran populasi maleo (Macrocephalon maleo) yang mempertahankan eksistensinya dari predator yang ditulis dalam bentuk sistem persamaan diferensial (SPD) sebagai berikut :

$$
\left.\begin{array}{rl}
\frac{d M}{d t} & =M r\left(1-\frac{M}{k}\right)+\gamma E-\delta M P+(1-\rho) T b \\
\frac{d T p}{d t} & =\alpha \theta M-\beta T p \\
\frac{d E}{d t} & =\beta T p-\gamma E-\mu_{1} E \\
\frac{d T b}{d t} & =\theta(1-\alpha) M-\rho T b P-(1-\rho) T b \\
\frac{d P}{d t} & =\varphi+\rho T b P+\delta M P-\mu_{1} P
\end{array}\right\}
$$

\subsection{Analisis Kestabilan dari Model}

\subsubsection{Titik Kritis dan Eksistensinya}

Titik kritis dari sistem persamaan (3) diperoleh dengan menyelesaikan persamaan-persamaan sebagai berikut:

$$
\frac{d M}{d t}=0, \frac{d T p}{d t}=0, \frac{d E}{d t}=0, \frac{d T b}{d t}=0, \frac{d P}{d t}=0
$$

Sehingga diperoleh 2 titik kritis, yaitu $T_{1}=\left(0,0,0,0, \frac{\varphi}{\mu_{1}}\right)$ dan $T_{2}=\left(M^{*}, T p^{*}, E^{*}, T b^{*}, P^{*}\right)$. dimana :

$$
\begin{aligned}
& M^{*}=\frac{E\left(\gamma+\mu_{1}\right)}{\alpha \theta}, T p^{*}=\frac{E\left(\gamma+\mu_{1}\right)}{\beta}, \\
& P^{*}=-\frac{E\left(r\left(E\left(\gamma^{2}+\mu_{1}\right)+2 E \mu_{1} \gamma\right)-\alpha \theta k\left(\gamma+\mu_{1}\right)\right)+k \alpha \theta^{2}\left(\mu_{1}(-1+\alpha)-\gamma\right)-\theta^{2} \alpha^{2} k \varphi}{\theta^{2} \alpha^{2} k \mu_{1}}, \\
& T b^{*}=-\frac{E^{2}\left(\gamma+\mu_{1}\right)\left(E \delta r\left(\gamma+\mu_{1}\right)^{2} \alpha^{2} \theta^{2} k\left(\mu_{1} \delta+r \mu_{2}\right)-\alpha \theta(k \delta(r+\theta))\left(\gamma+\mu_{1}\right)+E \alpha^{2} \theta^{2} k\left(\alpha \theta \mu_{2} \gamma-\varphi \delta\left(\gamma+\mu_{1}\right)\right)\right.}{\mu_{2} \theta^{3} \alpha^{3} k(1-\rho)}
\end{aligned}
$$

dengan $E^{*}$ memenuhi polinomial berikut ini:

$$
P(E)=a_{4} E^{4}+a_{3} E^{3}+a_{2} E^{2}+a_{1} E+a_{0}
$$

dimana :

$$
\begin{aligned}
a_{4}= & \delta r^{2} \rho\left(\gamma+\mu_{1}\right)^{5} \\
a_{3}= & -2 r \theta \alpha \rho\left(\gamma+\mu_{1}\right)^{3}\left(\mu_{1}\left(\delta k\left(r+(1-\alpha)+\frac{1}{2} r \mu_{2}\right)+\gamma\left(\delta k(r+\theta)+\frac{1}{2} r \mu_{2}\right)\right)\right) \\
a_{2}= & k \alpha^{2} \theta^{2}\left(\gamma+\mu_{1}\right)\left(\rho \left(\mu _ { 2 } \left(\mu _ { 1 } ^ { 2 } \left(2 r^{2}+r(\delta+\theta(1-\alpha))+2 \gamma \mu_{1}\left(2 r^{2}+r(\delta+\theta)\right)+\right.\right.\right.\right. \\
& \left.\gamma^{2}\left(2 r^{2}+r(\delta+\theta(1-\alpha))\right)\right)+k\left(\delta\left(\gamma\left(\gamma+\mu_{1}\right)^{2}(\delta+\theta)^{2}+\theta^{2} \delta \mu_{1}^{2} \alpha^{2}\right)-\delta(\gamma+\right. \\
& \left.\left.\left.\mu_{1}\right)\left(2 \mu_{1} \alpha \theta k(r+\theta)+2 \emptyset r\left(y+\mu_{1}\right)\right)\right)-\delta r \mu_{2}\left(\gamma+\mu_{1}\right)^{2}\right) \\
a_{1}= & -\theta^{3} \alpha^{3} k\left(\rho \left(k\left(\mu_{1}(r+(1-\alpha) \theta)+\gamma(\theta+r)\left(\mu_{1}(r+\delta)+\gamma(r+\delta+\alpha \theta)\right)\right)+\left(\gamma+\mu_{1}\right)\left(r \rho\left(\gamma+\mu_{1}\right) \mu_{2}^{2}\right.\right.\right. \\
- & r \mu_{2}\left(\gamma+\mu_{1}\right)\left(\rho \varphi+\mu_{2}\right)-\delta\left(k\left(2 \rho \varphi+\mu_{2}\right)\left(\mu_{1}(r+(1-\alpha) \theta)+\gamma(\theta+r)\right)\right) \\
a_{0}= & -\theta^{4} \alpha^{4} k^{2}\left(-\mu_{2}^{2}(-1+\rho)\left(\mu_{1}(r+\theta(1-\alpha))+\gamma(r+\theta)\right)+\varphi\left(\rho \mu_{2}\left(\gamma+\mu_{1}\right)(\delta+r)+\alpha \theta \gamma \rho \mu_{2}\right.\right. \\
- & \left.\delta\left(\gamma+\mu_{1}\right)\left(\rho \varphi+\mu_{2}\right)\right)
\end{aligned}
$$


Akar-akar $E^{*}$ dari polinomial (4) sulit ditunjukkan secara eksplisit. Namun, eksistensinya dapat ditentukan dengan menggunakan aturan Descartes. Berdasarkan kriteria Descrates, poliomial (4) memiliki minimal 1 akar positif $\left(E^{*}>0\right)$ jika terjadi 1 perubahan tanda koefisien. Mengingat koefisien $a_{4}$ adalah positif, maka agar terdapat paling sedikit 1 akar positif yang ditunjukan dengan terjadinya 1 perubahan tanda, haruslah $a_{3}, a_{2}, a_{1}$ dan $a_{0}$ bernilai negatif.

Karena $M^{*}$ dan $T p^{*}$ dijamin bernilai positif, maka eksistensi $T_{2}$ tercapai jika $T b^{*}, P^{*}$ dan $E^{*}$ bernilai non negatif. Sehingga diperoleh syarat eksis $T_{2}$ sebagai berikut: $\delta<\frac{r \mu_{2}\left(\gamma+\mu_{1}\right)\left(\rho \varphi+\mu_{2}\right)-r \rho\left(\gamma+\mu_{1}\right) \mu_{2}^{2}}{k\left(2 \rho \varphi+\mu_{2}\right)\left(\mu_{1}(r+(1-\alpha) \theta)+\gamma(\theta+r)\right.}, \mu_{2}<\frac{\varphi \delta\left(\gamma+\mu_{1}\right)}{\alpha \theta \gamma}$ dan $\theta>\frac{E\left(\gamma^{2}+\mu_{1}^{2}\right)+2 \mu_{1} \gamma E}{\alpha k\left(\mu_{1}+\gamma\right)}$

Syarat eksis $T b^{*}, E^{*}$ dan $P^{*}$ memberi arti bahwa agar titik kritis $T_{2}$ eksis maka tingkat kematian predator dan tingkat predasi terhadap populasi maleo harus dibatasi sedangkan persentase populasi maleo yang bertelur harus sebesar mungkin.

Titik kritis $T_{1}$ menggambarkan kondisi dimana populasi predator mengusai ekosistem di alam bebas wilayah konservasi dan mengakibatkan kepunahan terhadap populasi maleo, sedangkan $T_{2}$ merepresentasikan kondisi endemik dimana populasi maleo di alam bebas tetap berkembang, meskipun masih terjadi pemangsaan oleh predator.

\subsubsection{Kestabilan dari Titik Kritis}

Kestabilan dari titik kritis $T_{1}$ dan $T_{2}$ ditentukan berdasarkan nilai eigen dan memperhatikan koefisien-koefisien dari persamaan karakteristik untuk mengidentifikasi akar - akar karateristik yang dievaluasi di titik kritis $T_{1}=\left(0,0,0,0, \frac{\varphi}{\mu_{1}}\right)$ dan $T_{2}=$ $\left(M^{*}, T p^{*}, E^{*}, T b^{*}, P^{*}\right)$. Hasil tersebut memperlihatkan bahwa akar-akar persamaan karakteristik berupa polinom orde lima, sehingga perlu diperhatikan untuk memeriksa kemunculan akar-akar positif yang mengidentifikasikan ketidakstabilan di kedua titik kritisnya yang dinyatakan dalam bentuk

$$
a_{0} \lambda^{5}+a_{1} \lambda^{4}+a_{2} \lambda^{3}+a_{3} \lambda^{2}+a_{4} \lambda+a_{5}=0
$$

Dimana nilai masing-masing koefisien polinomial derajat 5 dalam $\lambda$ untuk $T_{1}$ sebagai berikut :

$$
\begin{aligned}
& a_{0}=-1 \\
& a_{1}=a+e+g+i+l \\
& a_{2}=h c+l(-g-a)+a(-g-e-i)+i(-e-l-g)+e(-g-l) \\
& a_{3}=d f b+h c(-e-g-l)+a(e g+e l+g i+i l+e i)+e(g i+g l+i l)+g(i l+a l)>0 \\
& a_{4}=d f b(-i-l)+h c(e g+e l+g l)+a e(-i l-g l-g i)+i l(-e g-a g)>0 \\
& a_{5}=d f b i l+\operatorname{leg}(a i-h c)<0
\end{aligned}
$$


Dengan,

$$
\begin{aligned}
a & =r-\frac{\delta \varphi}{\mu_{2}}, b=\gamma, c=1-\rho, d=\alpha \theta, e=-\beta, f=\beta, g=-\gamma-\mu_{1}, h=(1-\alpha) \theta, \\
i & =-\frac{\rho \varphi}{\mu_{2}}-(1-\rho), j=\frac{\delta \varphi}{\mu_{2}}, k=\frac{\rho \varphi}{\mu_{2}}, l=-\mu_{2}
\end{aligned}
$$

Sedangkan koefisien polinomial derajat 5 dalam $\lambda$ untuk $T_{2}$ sebagai berikut :

$$
\begin{aligned}
a_{0}= & -1 \\
a_{1}= & a+f+h+j+n \\
a_{2}= & k m+i c+l d+a(-f-h-j)+f(-h-j-n)+h(-j-n)+n(-j-a) \\
a_{3}= & i m d+i c(-h-n-f)+l(-h d-d j+c k-f d)+m(-f k-h k)+e g b+h(j n+ \\
& a(f+j+n))+a(f j+j n-k m)+f(h j+f h n+j n) \\
a_{4}= & i c(f n+h n+f h)+l f h d+h(-i m d-a j n-l c k)+f(-l c k-a j n-h j n-a h j-a h n-i m d) \\
& +d j(l h+l f)+k m(a h+a f+f h)+e g b(-j-n) \\
a_{5}= & e g b(j n-k m)+f h(l c k+a j n+i c n)+f(-a h k m-i h d j)
\end{aligned}
$$

Dengan,

$$
\begin{aligned}
a & =r-\frac{M^{*} r}{k}-\delta P^{*}, b=\gamma, c=1-\rho, d=-\delta M^{*}, e=\alpha \theta, f=-\beta, g=-\beta, h=-\gamma-\mu_{1}, \\
i & =(1-\alpha) \theta, j=-\rho P^{*}-(1-\rho), k=-\rho T b^{*}, l=\delta P^{*}, m=\rho P^{*}, n=\delta M^{*}+\rho T b^{*}-\mu_{2}
\end{aligned}
$$

Penentuan kestabilan dilakukan dengan metode Routh-Hurwitz dengan menyatakan persamaan (5) dalam Tabel Routh sebgai berikut :

Tabel 3 : Tabel Routh-Hurwitz $T_{1}$ dan $T_{2}$.

\begin{tabular}{|l|l|l|l|}
\hline$\lambda^{\mathbf{5}}$ & -1 & $\boldsymbol{a}_{2}$ & $\boldsymbol{a}_{\mathbf{4}}$ \\
\hline $\boldsymbol{\lambda}^{\mathbf{4}}$ & $a_{1}$ & $a_{3}$ & $a_{5}$ \\
\hline $\boldsymbol{\lambda}^{\mathbf{3}}$ & $b_{1}$ & $b_{2}$ & 0 \\
\hline $\boldsymbol{\lambda}^{\mathbf{2}}$ & $c_{1}$ & $c_{2}$ & 0 \\
\hline $\boldsymbol{\lambda}^{\mathbf{1}}$ & $d_{1}$ & 0 & 0 \\
\hline $\boldsymbol{\lambda}^{\mathbf{0}}$ & $e_{1}$ & 0 & 0 \\
\hline
\end{tabular}

dengan $b_{1}=\frac{\left(a_{1} a_{2}-a_{0} a_{3}\right)}{a_{1}}, b_{2}=\frac{\left(a_{1} a_{4}-a_{0} a_{5}\right)}{a_{1}}, c_{1}=\frac{\left(b_{1} a_{3}-a_{1} b_{2}\right)}{b_{1}}, c_{2}=\frac{\left(b_{1} a_{5}\right)}{b_{1}}=a_{5}$ $d_{1}=\frac{\left(c_{1} b_{2}-b_{1} c_{2}\right)}{c_{1}}, e_{1}=\frac{\left(d_{1} c_{2}\right)}{d_{1}}=a_{5}$

Kriteria Routh-Hurwitz memerlukan pemeriksaan terhadap setiap koefisen dan tidak adanya perubahan tanda pada kolom pertama. Karena nilai koefisien dari $a_{0}$ adalah negatif, maka perlu diperiksa apakah nilai-nilai dari $a_{1}, b_{1}, c_{1}, d_{1}$ dan $e_{1}$ bernilai negatif.

Karena $e, g, i$ dan $l$ pada koefisien persamaan karakteristik untuk $T_{1}$ adalah negatif, maka koefisien $a_{1}$ terpenuhi jika $a<0$. Sehingga memberikan syarat bagi $a_{1}<$ 
0 yaitu $\mu_{2}-\frac{\delta \varphi}{r}$. Sedangkan $f, h$ dan $j$ pada koefisien persamaan karakteristik untuk $T_{2}$ adalah negatif, maka koefisien $a_{1}$ terpenuhi jika $a<0$ dan $n<0$. Sehingga memberikan syarat bagi $a_{1}<0$ yaitu $\frac{r\left(k-M^{*}\right) \delta \varphi}{P^{*} k}<\delta<\frac{\mu_{2}-\rho T b^{*}}{M^{*}}$.

Dalam hal $a_{1}<0$, koefisien $b_{1}$ bernilai negatif jika $a_{1} a_{2}-a_{0} a_{3}>0$. Karena koefisien $a_{0}$ dan $a_{1}$ bernilai negatif, maka $a_{2}<0$ dan $a_{3}>0$ akan mengakibatkan $a_{1} a_{2}-$ $a_{0} a_{3}>0$. Sehingga di peroleh syarat koefisien $b_{1}<0$ pada persamaan karakteristik untuk $T_{1}$ yaitu $\alpha>1-\frac{A}{\theta(1-\rho)}$ dan $\theta>\frac{B}{\left(\alpha \beta \gamma+(1-\alpha)(1-\rho)\left(\beta+\gamma+\mu_{1}+\mu_{2}\right)\right)}$,

dimana :

$A=i l+a g+a l+g i+a e+a i+g l+e g+e i+e l)$

$B=-a(e g+e l+g i+i l+e i)-e(g i+g l+i l)-g(i l+a l)$

Sedangkan syarat koefisien $b_{1}<0$ pada persamaan karakteristik untuk $T_{2}$ yaitu $\alpha>1-\frac{A}{\theta(1-\rho)}$ dan $\theta>\frac{B}{(1-\alpha)(1-\rho)\left(\left(\gamma+\mu_{1}\right)-\left(\delta M^{*}+\rho T b^{*}-\mu_{2}\right)+\beta\right) \alpha \beta \gamma}$, dimana :

$A=-k m-l d-a(-f-h-j)-f(-h-j-)-h(-j-n)-n(-j-a)$ $B=-i m d+l(h d+d j-c k+f d)+m(f k+h k)+h(-j n-a(f+j+n)+a(-f j-$ $j n+k m)+f(-h j-h n-j n)$

Nilai $c_{1}$ pada kolom pertama Tabel Routh Hurwitz akan negatif jika $b_{1} a_{3}-a_{1} b_{2}>$ 0 . Karena koefisien $a_{1}$ dan $b_{1}$ pada persamaan karakteristik untuk $T_{2}$ dan $T_{2}$ bernilai negatif sedangkan koefisien $a_{3}$ bernilai positif, maka syarat $b_{2}>0$ dan $a_{1} b_{2}>b_{1} a_{3}$ akan mengakibatkan $b_{1} a_{3}-a_{1} b_{2}>0$. Selanjutnya akan diperiksa $b_{2}>0$.

Karena $a_{1}<0$, koefisien $b_{2}$ akan positif jika $a_{1} a_{4}-a_{0} a_{5}<0$. Karena koefisien $a_{0}$ dan $a_{1}$ bernilai negatif, maka $a_{4}>0$ dan $a_{5}<0$ akan mengakibatkan $a_{1} a_{4}-a_{0} a_{5}<$ 0 . Sehingga di peroleh syarat koefisien $b_{2}>0$ pada persamaan karakteristik untuk $T_{1}$ yaitu dan $D>\alpha \theta \beta \gamma \mu_{2}\left(\frac{\rho \varphi}{\mu_{2}}+(1-\rho)+\beta \theta\left(\gamma+\mu_{1}\right)(1-\alpha)(1-\rho)\right)$, dimana $D=-$ aegil

Sedangkan syarat koefisien $b_{2}<0$ pada persamaan karakteristik untuk $T_{2}$ yaitu $D>\alpha \theta \beta \gamma\left(-\rho P^{*}-(1-\rho)\left(\delta M^{*}+\rho T b^{*}-\mu_{2}\right)+\rho^{2} T b^{*} P^{*}\right)$, dimana $D=-f h(l c k+$ ajn + $i c n)-f(-a h k m-i h d j)$.

Karena $c_{1}<0$, koefisien $d_{1}$ akan bernilai negatif jika $c_{1} b_{2}-b_{1} c_{2}>0$. Karena koefisien $b_{1}, c_{1}$ dan $c_{2}=a_{5}$ bernilai negatif sedangkan $b_{2}$ bernilai positif mengakibatkan $c_{1} b_{2}-b_{1} c_{2}<0$, sehingga memberikan koefisien $d_{1}$ bernilai positif yang menunjukan terjadinya perubahan tanda pada kolom pertama tabel Routh-Hurwitz. Disimpulkan bahwa titik kritis $T_{1}$ dan $T_{2}$ adalah tidak stabil. 


\subsection{Simulasi}

Simulasi dilakukan untuk merepresentasikan dinamika pertumbuhan populasi maleo pada kondisi punah dan kondisi endimik. Pada bagian ini akan ditampilkan kurva yang menggambarkan pertumbuhan setiap populasi dalam ekosistem TNLL dengan menggunakan nilai parameter $r=0.0278, \mu_{1}=0.01111, \mu_{2}=0.00185, \delta=0.51, \varphi=0.0047, \rho=0.65, \alpha=$ $0.5, \theta=0.6, \gamma=0.5, \beta=0.65, k=1000$. Interval waktu pengamatan dibuat dalam tahun.

\subsubsection{Simulasi Kondisi Punah}

Kondisi punah ditunjukkan oleh nilai awal sub-populasi maleo (M), telur di alam bebas (Tb), maleo pada masa ekspous (E) dan telur di penangkaran (Tp) sebesar nol. Simulasi pada kondisi punah maleo pada interval $0 \leq t \leq 0,5$ dengan satuan waktu dalam tahun ditunjukan pada Gambar 2 berikut:

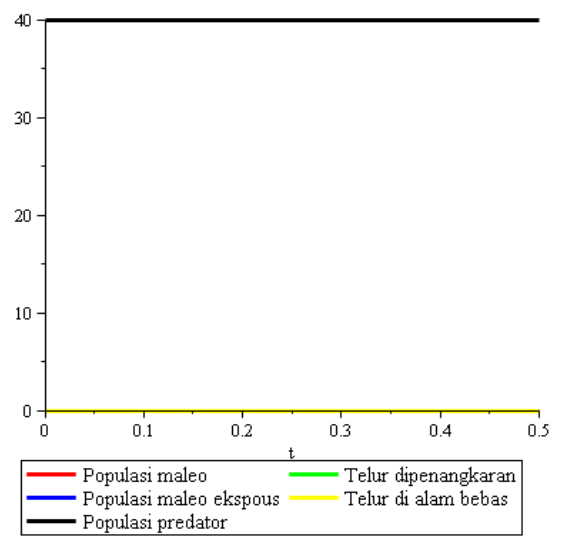

Gambar 2 : Kurva Simulasi Kondisi Punah Maleo Pada $0 \leq t \leq 0,5$ (Satuan waktu dalam tahun)

Gambar 2 memperlihatkan kondisi dimana tidak adanya sub populasi maleo dan telur di alam bebas wilayah konservasi pada waktu $0 \leq t \leq 0,5$ tahun atau dari bulan pertama hingga bulan ke-enam, sehingga menyebabkan tidak ada pula sub populasi maleo ekspous dan telur dalam penangkaran. Titik kritis punah $T_{1}=\left(0,0,0,0, \frac{\varphi}{\mu_{1}}\right)$ akan mengakibatkan kondisi dimana seluruh populasi maleo dan telurnya akan habis dan mengalami kepunahan. Sedangkan pertumbuhan populasi predator pada $0 \leq t \leq 0,5$ tahun atau dari bulan pertama hingga bulan ke-enam menjadi konstan. Kondisi ini menunjukkan eksisnya populasi predator meskipun tidak terdapat populasi maleo dan telurnya di alam bebas wilayah konservasi. Hal ini disebabkan karena populasi maleo dan telurnya bukan merupakan makanan utama predator dan interaksinya hanya sebatas perburuan. 


\subsubsection{Simulasi Kondisi Endemik}

Simulasi kondisi endemik dilakukan dengan menggunakan nilai awal populasi maleo ( $M=250$ ekor), telur di penangkaran $(T p=110)$, maleo pada masa ekspous $(E=20$ ekor), telur di alam bebas ( $\mathrm{Tb}=50$ butir) dan populasi Predator ( $\mathrm{P}=40$ ekor). Pengamatan pada masing-masing populasi dengan interval $0 \leq t \leq 0,5$ dengan satuan waktu dalam tahun ditunjukan pada Gambar 3a dan gambar 3b berikut:

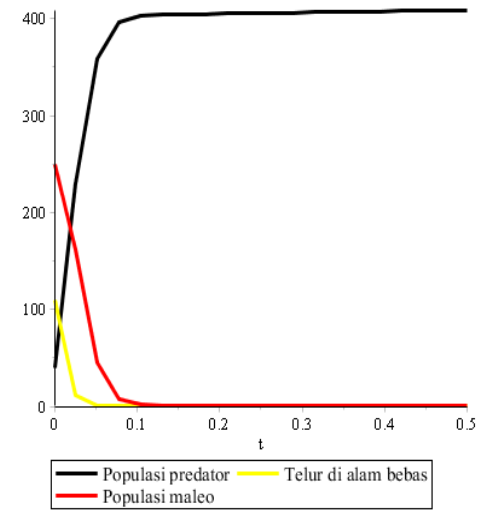

Gambar 3a : Kurva Simulasi Kondisi

Endemik di alam Bebas Wilayah

Konservasi pada $0 \leq t \leq 0,05$

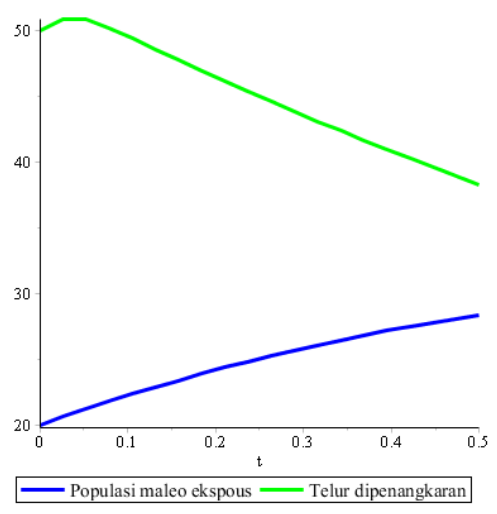

Gambar 3b : Kurva Simulasi Kondisi Endemik dalam penangkaran Wilayah Konservasi pada pada $0 \leq t \leq 0,08$

Pada Gambar 3a memperlihatkan pertumbuhan populasi maleo dan telurnya yang berada di alam bebas wilayah konservasi mengalami penurunan sangat cepat. Populasi maleo yang semula 250 ekor menurun menjadi 8 ekor dalam waktu $t=0,08$ tahun atau pada bulan pertama. Sedangkan populasi telur yang semula 110 butir berkurang hingga tersisa 1 butir hanya dalam kurun waktu $t=0,04$ tahun atau sekitar 15 hari. Pertumbuhan populasi maleo dan telurnya terus menurun hingga mencapai 1 ekor dan jumlah telur mendekati nol pada $t=0,5$ tahun atau pada bulan ke-6. Hal ini disebabkan adanya interaksi yang terjadi antara sub populasi maleo dan telurnya dengan predator di alam bebas wilyah konservasi. Hal ini merupakan indikasi keberhasilan tim penangkaran TNLL dalam memindahkan telur-telur di alam bebas untuk di pindahkan ke penangkaran. Jika penurunan ini terus terjadi maka dalam waktu tertentu telur di alam bebas wilah konservasi akan habis.

Menurunnya pertumbuhan populasi maleo dan telurnya yang di akibatkan perburuan yang dilakukan oleh predator di alam bebas wilayah konservasi, membuat pertumbuhan populasi predator yang semula 40 ekor dalam waktu singkat meningkat hingga menjadi 396 ekor atau mengalami kenaikan jumlah populasi sebesar 256 ekor 
dalam kurun waktu $t=0,08$ atau pada bulan pertama, kemudian terus meningkat hingga mencapai 409 ekor pada waktu $t=0,5$ tahun atau sekitar pada bulan ke-6.

Terlihat pada Gambar 3b bahwa banyaknya telur dalam penangkaran mengalami kenaikan dan penurunan, yang semula 50 butir meningkat hingga mencapai sebanyak 51 butir butir dalam waktu $t=0,04$ atau sekitar 15 hari, kemudian turun menjadi 50 butir pada $t=0,08$ tahun atau pada bulan pertama. Selanjutnya, jumlah telur terus mengalami penurunan hingga tinggal 38 butir pada saat $t=0,5$ tahun atau pada bulan ke-6. Penurunan jumlah telur hanya dipengaruhi dengan adanya telur yang menetas menjadi populasi maleo ekspous. Adanya telur yang menetas menjadi populasi maleo ekspous mengakibatkan sub-populasi pada masa ekspous sedikit demi sedikit mengalami kenaikan jumlah populasi. Gambar 3b menunjukan bahwa sub-populasi maleo ekspous yang semula 20 ekor meningkat menjadi sekitar 22 ekor di bulan pertama, kemudian terus meningkat hingga mencapai mencapai 29 ekor pada $t=0,5$ tahun atau bulan ke-6. Pada kondisi ini, populasi maleo pada masa ekspous tidak mengalami peningkatan populasi dengan cepat hal ini dikarenakan pertumbuhan populasi maleo pada masa ekspous dipengaruhi oleh banyaknya telur di penangkaran yang menetas. Dari Gambar 3b memperlihatkan bahwa populasi maleo pada masa ekspous i tidak terjadi penurunan jumlah populasi, hal ini menunjukkan keberhasilan tim penangkaran TNLL dalam memindahkan telur-telur di alam bebas ke penangkaran.

\section{KESIMPULAN}

Penelitian ini telah menawarkan pendekatan model dinamik penangkaran populasi maleo yang menggambarkan interaksi antara predator dan populasi-populasi yang mencerminkan perpindahan fase pertumbuhan maleo dalam ekosistem TNLL . Dari model tersebut diperoleh dua titik kritis, yaitu titik kritis $T_{1}$ dan yang menggambarkan kondisi punah maleo dan titik kritis $T_{2}$ yang menggambarkan kondisi endemik dinamika pertumbuhan maleo. Hasil analisa kestabilan menunjukkan sistem dikedua titik kritisnya tidak stabil. Hal ini disebabkan nilai-nilai dari kolom pertama pada tabel Routh Hurwitz mengalami perubahan tanda. Simulasi pada kondisi endemik memperlihatkan bahwa seiring berjalannya waktu, populasi maleo dan telurnya yang berada di alam bebas mengalami penurunan jumlah populasi sedangkan populasi ekspous tetap eksis. Kondisi endemik yang tidak stabil mengindikasikan upaya untuk menjaga eksistensi maleo melalui penangkaran di wilayah konservasi masih memerlukan dukungan upaya lain. 


\section{DAFTAR PUSTAKA}

[1] Campbell, S. L., \& Haberman, R., Introduction to Differensial Equitions with Dinamycal System, (2008), New Jersey: Princeton University Pree..

[2] Collar, N. J., Crosby, M. J., and Stattersfield, A. J., Bird to Watch 2, The World List of Threatened Birds. BirdLife Conservation Series No. 4. BirdLife International. Cambridge, (1994), United Kingdom.

[3] Laban, L. M., Penduggaan Preferensi Habitat Peneluran dan Pola Sebaran Maleo (Macrocephalon maleo Sal Muller 1846) Berdasarkan Keberadaan Sarang diKawasan Taman Nasional Lore Lindu Kabupaten Donggala Provinsi Sulawesi Tengah, Skripsi, Departemen Konservasi Sumberdaya Hutan Dan Ekowisata Fakultas Kehutanan Institut Pertanian Bogor 2007, (2007), Bogor.

[4] Drucker, D. S., A Second Look at Descartes' Rule of Signs: Mathematics Magazine, V. 52. No. 5 (sept), (1979), p. 237-238.

[5] Sasia, H., Koordinator Bidang PTN Wilayah 1 Saluki Taman Nasional Lore Lindu (TNLL) Sulawesi Tengah, (2016), Kabupaten Sigi.

[6] Subiono, Sistem linear dan Kontrol Optimal. Institut Teknologi Sepuluh Nopember, (2013), Surabaya. 